\title{
EXPLORING THE SPATIAL CONCENTRATION OF FOREIGN EMPLOYMENT IN POLAND UNDER THE SIMPLIFIED PROCEDURE
}

\author{
Agata Górny ${ }^{1}$ (D) Przemysław Śleszyński \\ ${ }^{1}$ Centre of Migration Research, Faculty of Economic Sciences \\ University of Warsaw \\ Krakowskie Przedmieście 26/28, 00-927 Warsaw: Poland \\ e-mail: agata@gorny.edu.pl \\ ${ }^{2}$ Institute of Geography and Spatial Organization \\ Polish Academy of Sciences \\ Twarda 51/55, 00-818 Warsaw: Poland \\ e-mail: psleszyn@twarda.pan.pl
}

\begin{abstract}
The unprecedented growth of immigration into Poland after 2013, especially from Ukraine, raises optimism among employers, and concerns among some social and political actors. The goal of this article is to contribute to that discussion, with a view to identifying a detailed geographical localisation of labour migrants employed under the simplified procedure (on the basis of employers' declarations of a consent to employ a foreigner) - as an important legal channel by which the influx of foreign workers into Poland is taking place. Analyses of the register of declarations for 2012-2017 reveal a certain weakening of the geographical concentration of the foreign labour force in Poland. The highest intensity of foreign employment has been observed in rural areas, while the greatest numbers of declarations for work have been registered in large cities. The geographical distribution of the foreign labour force in Poland has been shaped by activities of employment agencies especially in recent years.
\end{abstract}

\section{Key words}

immigration - Ukrainian migrants • foreign employment • seasonal employment • labour market - simplified procedure

\section{Introduction}

Immigration of foreigners involves a variety of consequences spanning different spheres of socio-economic life such as: the labour market, housing, education, social relations, family relations and many others (Castles, de Haas \& Miller 2014). These have already become an everyday reality in many European countries, but this is still not necessarily of the case for the Central and Eastern European (CEE) countries. The migration 
transition - whereby countries move from being characterised by net emigration to net immigration - has definitely not been completed in the post-communist part of Europe (Grabowska-Lusińska, Drbohlav \& Hars 2011). While the share of the population accounted for by foreigners in the four CEE countries regarded as 'immigration magnets' (i.e. Czechia, Hungary, Slovakia and Slovenia) did increase relatively dynamically over much of the last two decades (OECD, various years), the 2008 economic crisis slowed down or even reversed that trend (cf. Çağlar 2013). According to OECD data for 2017, the shares accounted for by foreigners in the total populations of the CEE countries did not exceed 2\% typically, except in Slovenia (7\%) and Czechia (4\%). Overall, then, the CEE countries are still characterised by relatively small proportions of foreign citizens in their populations, when compared with the rest of the European Union, where corresponding figures reach $10 \%$ in EU-15 countries, and range even higher in Western Europe.

It can be argued that Ukraine is the main reservoir of foreign labour coming into the CEE region (Prát \& Bui 2018). This despite the fact that Ukrainians do also go to other parts of the European Union (Vollmer 2016; Salaris \& Tedesco 2019). According to World Bank data, in 2017 the main European receiving areas chosen by Ukrainians were Germany, Italy and Poland, where the groups of Ukrainians exceeded 200,000, but also Czechia, where the numbers of Ukrainian migrants approached 140,000. Overall, the outbreak of the political crisis in Ukraine in 2013, followed by Russian-Ukrainian military conflict, resulted in an enormous intensification of emigration out of Ukraine, and especially into Poland (Drbohlav \& Jaroszewicz 2016; Gulina \& Pozniak 2018).

However, until recently, immigration into Poland has been a local phenomenon observable mainly in the Warsaw agglomeration, plus rural areas of the adjacent Mazowieckie Voivodeship (Górny et al. 2010; Klimek 2015). That situation changed in the wake of the Russian-Ukrainian military conflict. A gradual liberalisation of Polish immigration policy, especially with regard to the employment of foreigners in Poland, paved the way for large numbers of Ukrainian workers to be accommodated on the Polish labour market in the years 2014-2017 (Górny et al. 2018; Sokołowicz \& Lishchynskyy 2018). Consequently, more and more Polish cities and also rural areas have been sharing the experience involving the presence of foreign workers on their local labour markets (Jakóbczyk-Gryszkiewicz 2018; Niewiadomska \& Sobolewska-Poniedziałek 2019). However, little is known about the local dimension to these processes, not least when it comes to both the detailed geographical distribution of these foreign workers (on a level below NUTS3), and the consequences of their presence for local communities and their economies. The work presented in this article has sought to fill that gap.

From 2014 onwards, it has been possible to observe an unprecedented increase in numbers of all categories of immigrants - settlers, workers, students and others (Górny \& Kindler 2018). According to Eurostat data, Poland became the EU leader in terms of the number of first permits issued to foreigners in 2016. A recent estimation from the Central Statistical Office - in regard to overall numbers of foreigners by reference to various kinds of data source - is of 744,000 adult foreigners living in Poland in 2016. Almost all of these were of productive age, and a majority $(61 \%)$ originated from Ukraine (CSO 2018). Indeed, although Ukrainian citizens have consistently represented the main group of foreigners in Poland over the last two decades, the present trend is actually for a 'ukrainisation' of immigration into Poland (see Wendt et al. 2018). While the number of foreign card of residence holders doubled between 2014 and the beginning of 2018, there was fourfold growth in the numbers of Ukrainian holders of such cards. Furthermore, these figures fail to offer an adequate portrayal of the dynamics to labour immigration into Poland in recent years (Górny \& Kindler 2018). For 
example, 2017 brought the registration of as many as 1.8 million declarations of consent to employ a foreigner (mainly for seasonal work). 94\% of these went to Ukrainians, as did $82 \%$ of the more than 235,000 work permits issued. Overall, a sevenfold increase in the number of documents issued to foreigners in relation to work has been observed in Poland since 2014.

The above data clearly demonstrate that the greater part of the dynamic influx of foreigners, especially Ukrainians, into Poland happening in recent years has entailed seasonal labour migration (see also Duszczyk \& Matuszczyk 2018). This is not a novelty of recent years, since a highly temporary nature of immigration has been a feature characterising the influx of foreigners into Poland, mainly from Ukraine and other exUSSR countries, since the late 1980s (Górny et al 2010, Górny 2017, Iglicka \& Gmaj 2013). The main sectors in which Ukrainian workers have gained employment are agriculture, construction and domestic services (Brunarska et al. 2016). Only in last few years has it proved possible to observe a development of new foreign niches on the Polish labour market - mainly in trade and services, but also in processing industry (Górny et al. 2018; Górny \& Kaczmarczyk 2018).

It can thus be argued that dynamic changes with regard to immigration and the employment of foreigners on the Polish labour market are in progress. Little is known about the local dimension to these processes, which will definitely grow further in importance in the coming years. The goal of the work detailed here has thus been to help fill the gap by examining the status quo and dynamics of changes with regard to detailed geographical distribution - in Poland's cities and gminas (i.e. communes) - of foreign workers, and to consider the intersection with sectoral concentration (i.e. labour specialisation).

Analyses presented in this article refer to the (numerically) main channel of inflow of foreign workers into Poland known as the simplified procedure of employment, on the basis of employers' declarations of consent to employ a foreigner in the seasonal employment context. On the basis of such declaration by employers, there is a possibility of foreigners from Armenia, Belarus, Georgia, Moldova, Russia and Ukraine obtaining a visa entitling them to work in Poland for at most 6 months during each 12-month period.

Poland brought in the simplified procedure in 2006, to provide for fast, easy and cheap employment of foreign workers mainly in the agriculture (the registration of a declaration by an employer was free of charge $)$. In 2018, the procedure was modified to ensure a higher level of control over the employment of foreigners. Moreover, a new type of work permit - the seasonal work permit entitling foreigners to work for 9 months over 12-month period - was introduced for employment in agriculture and seasonal branches (for more on such changes to the simplified procedure, see Górny et al. 2018). However, as it remains difficult to evaluate how these changes impacted upon labour immigration into Poland, our analyses do not extend to the year 2018.

\section{Data}

Analyses presented in this article are based on register of employers' declarations of consent to employ a foreigner for the years 20122017, as kept by Poland's Ministry of the Family, Labour and Social Policy. Additionally, general reports on numbers of declarations by their selected characteristics referring to employees and their employment - published by the Ministry ${ }^{2}$ - were used as a supplementary data source, which includes full information for earlier years. The set of register data was compiled gradually, only commencing from 2012 (see Górny et al. 2018). This is to say that, for the years 2012-2014, it covers around $85 \%$ of the declarations registered in Poland. By 2015 coverage

\footnotetext{
1 From 2018 on, the cost of registration has been 30 PLN (about 7 EUR).

2 http://psz.praca.gov.pl/rynek-pracy/statystyki-ianalizy/zatrudnianie-cudzoziemcow-w-polsce
} 
had reached $90 \%$, while the register data for 2016-2017 can be considered complete (Tab. 1). For these reasons, our analyses focus in on the three-year period 2015-2017, as also coinciding with the most dynamic growth in immigration into Poland at any time in recent decades.
Declarations from employers were aggregated by planned place of performance of work. Due to the fact that these data are declarative only, their reliability should be approached with great caution. For example, according to research by the Centre of Migration Research of the Univer-

Table 1. Employers' declarations of a consent to employ a foreigner according to data source (reports and the register of Ministry of Family, Labour and Social Policy) in 2012-2017 (in thousand)

\begin{tabular}{|l|c|c|c|c|c|c|c|}
\hline \multicolumn{1}{|c|}{ Source } & 2012 & 2013 & 2014 & 2015 & 2016 & 2017 & Total \\
\hline Reports of Ministry of Family, Labour and Social Policy & 243.7 & 235.6 & 387.4 & 782.2 & $1,314.1$ & $1,824.5$ & $4,787.6$ \\
Register of Ministry of Family, Labour and Social Policy & 211.6 & 194.6 & 326.6 & 718.6 & $1,301.7$ & $1,817.9$ & $4,571.1$ \\
Share of declarations included in the register & $86.8 \%$ & $82.6 \%$ & $84.3 \%$ & $91.9 \%$ & $99.1 \%$ & $99.6 \%$ & $95.5 \%$ \\
\hline
\end{tabular}

Source: own elaboration based on data of Ministry of Family, Labour and Social Policy.

The register includes information about: date of declaration's registration, planned time of commencement and termination of work, basic data on the foreign worker (nationality, gender and year of birth), place of employer's registered office and place of performance of work (to gmina level), type and character of work (public or private sector, section of the Polish Classification of Activities (PKD), planned duration of work (in days), planned number of stays in Poland for the given post) and planned wage of foreigner. Such data are detailed enough to allow for the identification of key socio-economic and spatial trends characterising labour immigration into Poland on the basis of the simplified procedure.

Data have been aggregated into a uniform database of gminas for the whole analysed period 2012-2017. Only a very small proportion of observations (around 1\%) have not been ascribed to a location due to incorrect TERYT codes and names of gminas. Consequently, results presented in this article differ slightly from official reports issued by the Ministry of Family, Labour and Social Policy, in relation to the national and Voivodeship levels. However, the impact as regards the spatial diversification of the phenomenon under study should be seen as limited. sity of Warsaw (CMR), numbers of registered declarations are higher than numbers of foreign workers eventually taking up employment in Poland, and the estimated rate of use of declarations is at a level around $70 \%$. The rate in fact differs from one Polish Voivodeship to another, within the overall range 55\%-80\% (Górny et al. 2018). However, the research referred to does not allow for estimates at the level of each gmina to be made, so our analyses use raw register data on the number of declarations. While this kind of approach has some limitations, it does allow for an in-depth delineation of the spatial nature of foreign employment in Poland. In particular, it allows for the identification of locations in which volumes of foreign workers are particularly high, as well as for an assessment of the dynamics of changes in them over time.

\section{Basic information \\ - foreign-employment dynamics and distribution by sector, along with a presentation of selected characteristics of foreign workers}

According to the register data (for 82.6-99.6\% of all cases), some $4,788,000$ declarations 
were registered in Poland in the 2012-2017 period, among them $1,824,000$ dating from 2017 (Tab. 1). Numbers have been growing dynamically since 2012, following the same seasonal pattern each year, with steady growth in numbers of declarations trough to late spring, as followed by a decrease in successive months (Fig. 1). This seasonal pattern proved to be particularly strong in the earlier years of the period under study. What follows from Figure 1 is that, in the first months of 2012, the number of declarations registered daily approached 2,000 (among the $86.8 \%$ of declarations covered by the registry), as compared to almost 10,000 by 2017 (with $100 \%$ coverage of declarations). activities within the simplified procedure. For example, the share of declarations issued for processing industry grew from $8.1 \%$ in 2012 to $12.8 \%$ in 2017, while the corresponding figures for transport were $2.7 \%$ and $4.5 \%$.

What attracts the attention is the sharp increase in the proportion of declarations registered in section $N$, relating to administrative and support service activities: from $9.9 \%$ in 2012 to $31.2 \%$ in 2017. Almost $90 \%$ of these declarations $(640,700$ in total in 2017) were registered for only three PKD sections, i.e. temporary employment agency activities, activities of employment placement agencies and other human resources

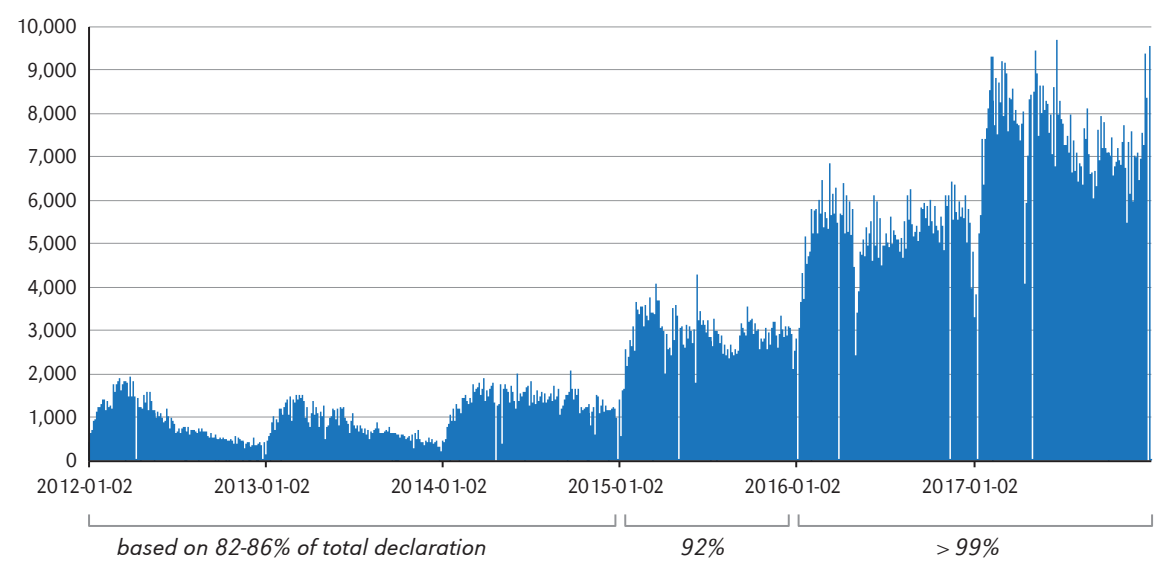

Figure 1. Daily number of declarations of consent to employ a foreigner registered by employers in Poland in 2012-2017, in given months

Source: on the basis of data from the Ministry of Family, Labour and Social Policy.

A weakening of the seasonality characterising registration of declarations in Poland in successive years corresponds with changes in the distribution of sectors (as described by PKD sections) for which they were being issued (Tab. 2). This is mainly to say that the share of declarations issued for agriculture decreased over the analysed period overall: from $47.0 \%$ in 2012 to $15.9 \%$ in 2017. This represents a change from strictly seasonal employment, related mainly to the calendar for farm work, into more diversified forms encompassing a broader spectrum of job provision. This demonstrates the growing role of employment agencies as employers registering declarations for foreign workers in Poland. This also implies a challenge when it comes to reconstructing the sectoral specialisation of migrants employed under the simplified procedure in Poland. The results of a survey of employment agencies registering declarations for foreigners in 2016, conducted by CMR, suggest that they above all send workers to sectors like: processing industry, construction and also transportation and storage (Górny et al. 2018). At the 
Table 2. Employers' declarations of a consent to employ a foreigner by PKD (Polish Business Classification) section of an offered job in Poland in 2012-2017

\begin{tabular}{|l|r|r|r|r|r|r|r|}
\hline \multirow{2}{*}{ Sector (PKD section) } & 2012 & 2013 & 2014 & 2015 & 2016 & 2017 \\
\cline { 2 - 8 } & \multicolumn{7}{|c|}{$\%$} \\
\hline Agriculture (A) & 47.0 & 57.8 & 51.2 & 36.1 & 24.4 & 15.9 \\
Mining (B) & $<0.1$ & $<0.1$ & $<0.1$ & $<0.1$ & 0.1 & 0.1 \\
Processing industry (CDE) & 8.1 & 8.1 & 10.5 & 12.8 & 12.9 & 12.8 \\
Construction (F) & 16.4 & 7.1 & 9.0 & 11.6 & 11.9 & 11.5 \\
Trade (G) & 3.9 & 6.3 & 4.9 & 5.3 & 4.5 & 3.9 \\
Transport (H) & 2.7 & 2.1 & 2.9 & 3.8 & 4.4 & 4.5 \\
Tourism (I) & 1.6 & 1.1 & 1.2 & 1.4 & 1.8 & 2.3 \\
Other services (J-U) & 7.2 & 5.8 & 5.9 & 7.1 & 5.4 & 4.2 \\
Administrative and support service activities (N) & 9.9 & 9.3 & 12.4 & 19.4 & 29.7 & 39.2 \\
Missing data & 3.2 & 2.4 & 1.9 & 2.5 & 4.8 & 5.7 \\
\hline Total & 100.0 & 100.0 & 100.0 & 100.0 & 100.0 & 100.0 \\
\hline
\end{tabular}

Source: based on data from Poland's Ministry of Family, Labour and Social Policy.

same time, it is difficult to assess the importance of the practice (not always fully legal) of agencies to send foreigners employed within the simplified procedure to other countries.

The increasing role of the employment agencies as regards the simplified procedure is also portrayed by reference to the growing average distance between the place of an employer's registered office and the place in which foreign workers actually perform their work, as calculated on the basis of centroids of gminas. While this distance was in the range $6.1-7.4 \mathrm{~km}$ as of 20122014, at $16.0 \mathrm{~km}$ in 2015 and at 30.2 in 2016 (Tab. 3), by 2017, it had gone as high as $38.5 \mathrm{~km}$, while the share of jobs offered in employers' registered offices was at only 73.9\%. As regards remaining offers, the greater the distance the smaller the numbers of offers observed. The share of declarations relating to situations in which the distance between the employer's registered office and the place of performance of work exceeds $165 \mathrm{~km}$ was around $10 \%$ as of 2017. It is worth noting that such a tendency may also reflect the growing importance of large companies (with a central office and several branches) as employers resorting to the simplified procedure.

At the same time, the mean declared duration of work done by foreigners in Poland declined from 172 days in 2012-2013 to 150 in 2017. The figure nevertheless remains very close to the maximal possible duration of work under the simplified procedure, i.e. 6 months during one year. The shortening of the mean declared time over which work was done can be related to the way in which the share of declarations registered for foreigners already staying in Poland (on the basis of a visa or a residency card) grew from $12.7 \%$ in 2012 to as much as $41.4 \%$ in 2017. This means that declarations have gained more and more frequent use in legalising the work of foreigners for a specific period of time related to the given post (possibly shorter than 6 months). It might also be linked to investigative activity pursued by the Border Guard and the National Labour Inspectorate with a view to eliminating cases in which foreigners work, not only for employers who register declarations for them, but also for other employers. Research conducted in the 
agricultural sphere suggests that such checks raised the level of awareness among famers as to the illegality of this kind of practice, with the result that more and more employers decide also to register declarations for workers already in possession of declarations registered by other employers (cf. Górny et al. 2018). This has ensured a gradually diminishing role for the declaration as a legal channel by which to enter Poland, notwithstanding the

\section{Spatial distribution}

The spatial distribution of registered declarations per 100 persons of productive age is portrayed on 6 maps by place of performance of work in 2012-2017 (Fig. 2). These demonstrate a year-on-year extension of the area in which the intensity of foreign employment is growing. At the beginning of the

Table 3. Employers' declarations of consent to employ foreigners, by selected features of the jobs offered and characteristics of the foreign workers in Poland, in the years 2012-2017

\begin{tabular}{|c|c|c|c|c|c|c|c|}
\hline Characteristics & 2012 & 2013 & 2014 & 2015 & 2016 & 2017 & Total \\
\hline Share of Ukrainian nationals $(\%)^{1}$ & 91.8 & 92.3 & 96.3 & 97.5 & 96.1 & 94.0 & 95.0 \\
\hline Share of men $(\%)^{1}$ & 61.6 & 55.4 & 61.6 & 66.3 & 65.8 & 65.0 & 63.1 \\
\hline $\begin{array}{l}\text { Share of foreigners already possessing visas } \\
\text { or residence permits }\end{array}$ & 12.7 & 14.6 & 20.8 & 27.8 & 33.6 & 41.4 & 29.4 \\
\hline Mean age of a foreigners (in years) $)^{2}$ & 35.5 & 35.9 & 34.9 & 34.4 & 34.6 & 34.8 & 34.7 \\
\hline Mean declared duration of work (in days) $)^{2}$ & 172 & 172 & 159 & 157 & 155 & 150 & 155 \\
\hline $\begin{array}{l}\text { Mean distance between employer's registered office } \\
\text { and place in which work is performed }(\mathrm{km})^{2}\end{array}$ & 7.2 & 6.1 & 7.4 & 16.0 & 30.2 & 38.5 & \\
\hline
\end{tabular}

Notes: ${ }^{1}$ calculations based on reports from the Ministry of Family, Labour and Social Policy; ${ }^{2}$ calculations based on registration by the Ministry of Family, Labour and Social Policy (including 82.6-99.6\% of all cases, see Tab. 1).

Source: based on data from the Ministry of Family, Labour and Social Policy.

crucial status in earlier years (Szulecka 2016).

As regards characteristics of foreigners employed in Poland under the simplified procedure, data from the register only represent approximate figures, as they relate, not to the group of workers, but to the dataset of declarations. However, it is clear that Ukrainians predominate among recipients of declarations. In various years, the share of declarations registered for them ranged from $91.8 \%$ (2012) to 97.5\% (2015) (Tab. 3). The proportions of declarations assigned to men were also relatively high during the analysed period, with the figure oscillating around 60\% in the years 2012-2014, only to reach 65.0$66.3 \%$ in 2015-2017. At the same time, the mean age of foreign workers was very stable through the period 2012-2017: at between 34.4 and 35.9 (on the basis of $91.9 \%$ of all cases). analysed period, the main concentration was in Mazowieckie Voivodeship, particularly areas to the north and south of Warsaw. The gminas involved are known for their intensive fruit and vegetable production, and hence the possibility of jobs in the Polish farm sector being on offer. In the later years, an increasing intensity of registered declarations was also recorded in Lubuskie and Dolnośląskie Voivodeships, as well as in the western part of Lubelskie.

Interestingly, eastern Poland - which might be expected to be a convenient destination for Ukrainian migrants given its proximity to the eastern Polish border - attracts a relatively small number of workers (registered declarations). This fact is explicable in terms of the peripheral character of this region, which is suffering from a disadvantageous economic structure and is considered 

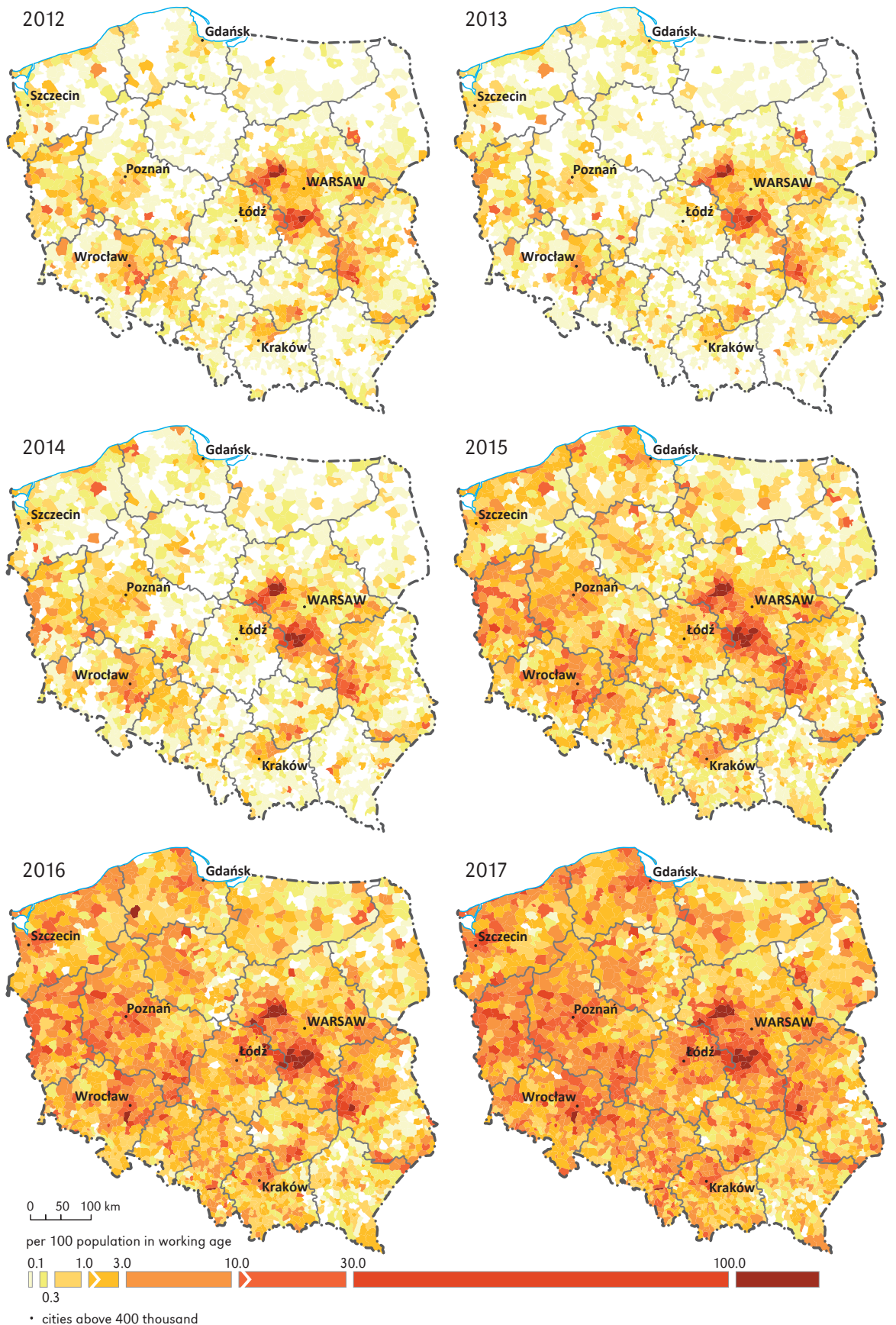

Figure 2. Changes in intensity of registration of employers' declarations of consent to employ a foreigner (number of documents per 100 persons of productive age), by gminas in Poland, in the years 2012-2017 Notes. Calculations in line with declared place of performance of work, as based on $82.6-99.6 \%$ of all cases (see Tab. 1).

Source: based on data from the Ministry of Family, Labour and Social Policy. 
socio-economically problematic (Śleszyński et al. 2018).

Apparently, it is demand for (foreign) workers that constitutes a key determinant of the spatial distribution of the foreign labour force in Poland. This is so, despite the inflow from Ukraine into Poland being regarded as supplydriven, due to strong push factors in Ukraine (the political situation and related economic crisis) (Drbohlav \& Jaroszewicz 2016). The role of employment agencies in shaping this tendency should not be neglected, since these are very flexible in reacting to labour-market needs. At the same time, their activities under the simplified procedure prove more dynamic in western Poland (Fig. 4).

The role of agencies can be the factor contributing to the relatively limited inflow of labour migrants also into the larger towns of eastern Poland. Among these, only Lublin stood out in 2017 , with its 16,800 registered declarations (by place of performance of work). However, this is an academic centre popular among Ukrainian students, and also a city with a long tradition of cultural relations with Ukraine (cf. Hofman 2013). By comparison, only 4,500 declarations were registered in Białystok in 2017. In other eastern towns some larger inflows (relative to the population of productive age) have been observed in Suwałki $(4,100)$, Lubartów (2,800) and Zambrów (2,600). It is difficult to judge the reason for these relatively small towns of 20,000-70,000 inhabitants (rather than others) to attract relatively large numbers of foreign workers.

The process by which labour immigration expands into new regions of Poland can be depicted in relation to changing values for the Lorenz asymmetry coefficient across the 2012-2017 period (Fig. 3). In 2012, a very high value for this coefficient offered an effective portrayal of the spatial fragmentation

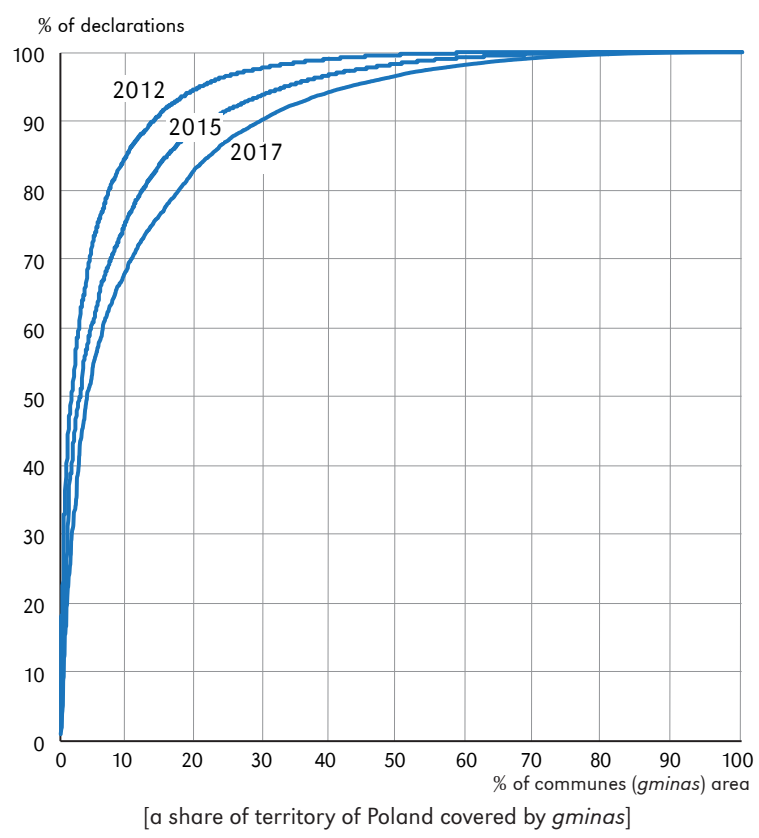

Figure 3. Lorenz asymmetry coefficient for distribution of registered employers' declarations of consent to employ a foreigner, by Polish gminas, in 2012, 2015 and 2017

Notes. Calculations by declared place and area of performance of work, on the basis of $82.6-99.6 \%$ of all cases (see Tab. 1).

Source: based on data from the Ministry of Family, Labour and Social Policy. 
of labour immigration into Poland observable from the late 1990s onwards (Fihel 2006; Górny et al. 2010): 90\% of declarations were registered in gminas accounting for just 14\% of the Polish territory. In contrast, as early as in 2017, the respective coverage-ratio had already extended to almost 30\%. The fiveyear period thus brought a doubling of the dispersion of declarations, even if the spatial concentration of foreign workers employed in Poland under the simplified procedure remained high.

In turn, the map in Figure 4 shows absolute numbers of declarations registered in Polish gminas in 2017 (by place of work). It shows the main regions of concentration, such as the agricultural centres in Mazowsze and the Lublin region. Also noteworthy is the marked concentration of the labour force employed under the simplified procedure that is present in various gminas in Śląskie Voivodeship, where the vast majority of declarations in 2017 were registered by employment agencies. In fact, agencies as employers under the simplified procedure play a crucial role in a majority of the places where the volumes of declarations are relatively high, in particular in the neighbouring Ślaskie, Opolskie and Dolnośląskie Voivodeships. This raises a question regarding the role of the already wellestablished infrastructure of agencies in this region as a successor of the dynamic activities of agencies in recruiting Polish workers (often with German passports) to work in Germany as early as in the 1990s (Napierała \& Fiałkowska 2013; Solga 2017).

Figure 4 makes it clear that foreign workers employed under the simplified procedure concentrate in Poland's large cities first and foremost. Table 4 shows the top 10 Polish gminas by numbers of registered declarations (for work in these gminas), and this list is seen to consist almost solely of such cities. The only exception is the gmina of Czerwińsk nad Wisła (ranked $6^{\text {th }}$, with its 35,100 declarations), which constitutes a centre for the growing of fruit and vegetables. In 2017, most declarations were registered in Wrocław $(63,100)$, followed by Poznań $(50,000)$, Łódź
$(49,900)$ and Kraków $(48,300)$. Interestingly enough, Warsaw, with its 44,100 declarations, does not take first place, but is a mere fifth in the ranking, despite the fact that the wider Mazowieckie Voivodeship is the unquestionable leader with regard to numbers of declarations registered in Poland in 2017. However, this does not have to imply that the total volume of labour migrants was smaller in the capital city than in other Polish cities. It can rather indicate that foreign workers in Warsaw enjoy a more stable residence and work status than migrants in other cities. In particular, they are more often employed on the basis of work permits. For example, in 2017, as many as 75,400 work permits were issued in Mazowieckie Voivodeship, as compared to 12,300 in Lower Silesia. At the same time, only $3.5 \%$ of these permits $(2,500)$ were issued to farm workers. In fact, almost half of these work permits were designated in relation to the construction, domestic-services, wholesale and trade, and hotel, restaurant and catering sectors. These offer jobs are far more characteristic of city than of rural labour markets (indeed mainly the Warsaw labour market). These are also sectors in which, according to earlier studies, Ukrainian migrants have been finding employment in the Warsaw agglomeration in recent years (Górny 2017; Górny \& Kaczmarczyk 2018).

The ranking for intensity of employment in various Polish communes reveals a totally different picture. If we consider the ratio involving numbers of declarations per 100 people of productive age, the top 10 gminas in 2017 are all but one seen to be located in rural areas (Tab. 4). Moreover, a majority of these rural localities are centres engaged in the production of fruit and vegetables, while all are located in Mazowieckie Voivodeship. Gminas in which the rate of foreign employment was highest in 2017 include: Czerwińsk nad Wisła (751.0 per 100 persons of working age), Załuski (370.3), Jasieniec (224.4), Goszczyn (223.1) and Promna (213.6). The only municipal gmina present (and taking third position in the ranking) is Goczałkowice-Zdrój (239.4), 
Table 4. Top 10 cities and gminas in terms of the absolute and relative numbers of employer declarations of consent to employ foreigners in Poland in 2017

\begin{tabular}{|c|c|c|c|}
\hline \multirow{2}{*}{ Name } & \multirow{2}{*}{$\begin{array}{c}\text { Population in } 2017 \\
\text { ['000] }\end{array}$} & \multicolumn{2}{|c|}{ Number of registered declarations } \\
\hline & & {$\left[{ }^{\prime} 000\right]$} & $\begin{array}{l}\text { per } 100 \text { persons } \\
\text { at working age }\end{array}$ \\
\hline \multicolumn{4}{|c|}{ Top 10 gminas with the highest absolute numbers of declarations } \\
\hline Wrocław & 638.6 & 63.3 & 16.5 \\
\hline Poznań & 538.6 & 50.0 & 15.6 \\
\hline Łódź & 690.4 & 49.9 & 12.5 \\
\hline Kraków & 767.3 & 48.3 & 10.4 \\
\hline Warsaw & $1,764.6$ & 44.1 & 4.3 \\
\hline Czerwińsk nad Wisła & 7.7 & 35.1 & 751.0 \\
\hline Gdańsk & 464.3 & 34.6 & 12.6 \\
\hline Szczecin & 403.9 & 24.2 & 10.0 \\
\hline Zielona Góra & 139.8 & 22.3 & 26.7 \\
\hline Katowice & 296.3 & 21.3 & 12.0 \\
\hline \multicolumn{4}{|c|}{ Top 10 gminas with the highest relative numbers of declarations } \\
\hline Czerwińsk nad Wisła & 7.7 & 35.1 & 751.0 \\
\hline Załuski & 5.7 & 13.0 & 370.3 \\
\hline Goczałkowice-Zdrój & 6.7 & 10.0 & 239.4 \\
\hline Jasieniec & 5.4 & 7.3 & 224.4 \\
\hline Goszczyn & 3.0 & 4.1 & 223.1 \\
\hline Promna & 5.6 & 7.3 & 213.6 \\
\hline Błędów & 7.6 & 9.4 & 208.6 \\
\hline Naruszewo & 6.4 & 8.1 & 208.4 \\
\hline Belsk Duży & 6.6 & 7.5 & 188.7 \\
\hline Wyszogród & 5.6 & 6.3 & 183.6 \\
\hline
\end{tabular}

Notes. Calculations based on declared places of performance of work, in relation to $99.6 \%$ of all cases (see Tab. 1).

Source: based on data from the Ministry of Family, Labour and Social Policy.

which is located in the southern part of Ślaskie Voivodeship. It is worth noting the key and evident fact that numbers of declarations registered in the 10 gminas in question were several times greater than the numbers of inhabitants of productive age resident in those areas. Indeed, in Czerwińsk nad Wisła, the value of the ratio exceeded $7^{3}$. These figures

\footnotetext{
3 However, it should be mentioned that, as earlier studies make clear, the declarations' use-ratio is likely
}

demonstrate the enormous relative importance of foreign labour force in these local (agricultural) labour markets particularly exceptional for Poland as a whole.

to be lower than the average of $70 \%$ for Poland due to the fact that farmers from this location have been known to register more declarations than they need (Górny et al. 2018). 


\section{Conclusions}

The results presented here allow several important observations to be formulated in regard to spatial and structural trends characterising the dynamically developing inflow of labour immigration under Poland's socalled simplified procedure, over the last five years. The ratio between the volume of foreign workers and numbers of declarations studied is only at around 70\% (Górny et al. 2018). However, we believe that, given the lack of detailed spatial analyses of immigration into Poland, the obtained results do contribute much to the identification of specific local features where foreign employment in Poland is concerned. A key starting point has thus been provided for further studies acknowledging the role of regions and local economies in shaping immigration into Poland.

As in earlier years (Górny \& Kaczmarczyk 2018), we observe strong ongoing spatial concentration of the foreign labour force in areas of intensive fruit and vegetable production, as related to employment in Polish agriculture. This above all applies to selected areas of Mazowieckie Voivodeship and the western part of Lubelskie Voivodeship. Intensity of foreign employment relative to the population of productive age is particularly high in these areas. Nevertheless, when it comes to absolute numbers of declarations, it continues to be the large cities that are the main recipients of the foreign labour force. However, the 2017 data reveal that it is not the labour market in Warsaw (for decades the leading destination area for labour migrants into Poland (Górny 2017)) that attracts the greatest number of foreign workers under the simplified procedure, but rather Wrocław, Poznań, Łódź and Kraków, where numbers of documents issued are all greater than in the Polish capital. The latter cities have apparently become the new municipal destinations in Poland, even if Warsaw remains the leader where the issue of work permits is concerned. More in-depth analyses for the gminas within Mazowieckie Voivodeship would be needed to offer fuller support for this observation.

At the same time, though declarations in Poland in 2017 remained very concentrated geographically, this had already followed a gradual weakening of the tendency over the 2012-2017 period. Regions of growing importance as receiving areas over recent years include Wielkopolskie, Lubuskie and Dolnoślaskie Voivodeships. The observed downward trend for the spatial concentration of declarations implies that large cities and farming areas are now being joined by locations more diverse in terms of functional characteristics and size as key destinations for labour immigrants. It is furthermore clear that the model for the geographical distribution of labour immigration into Poland - characterised by ongoing dispersion as it is - has some geographical relationship with the existence of supply-gaps on the Polish labour market. According to some estimations, by 2050, that gap will be of 2.2-6.9 million workers for the country as a whole. Moreover, in relative terms (the number of jobs relative to the size of professionally active population), this will be more of an issue for administrative units located beyond agglomerations (Śleszyński 2018). At the same time, the geographical dispersion of labour immigration into Poland can be seen as not benefiting Poland's medium-sized or small towns, given a level of supply on labour markets low enough to challenge the very economic bases of these urban centres (Krzysztofik \& Szmytkie 2018).

Another factor shaping the model of the geographical localisation of labour immigration into Poland under the simplified procedure entails increased activity on the part of employment agencies as employers, with an associated increasing in the average distance separated employers' registered offices and the actual place of performance of work. From the perspective of labourmarket effectiveness, this can be seen as a positive step, given the greater efficacy and flexibility of professional agencies (as 
opposed to 'ordinary' employers) in reacting to demand-supply mismatches on the job market. The development can also be taken to indicate the Polish labour market becoming more 'civilized', though such an optimistic claim should be formulated with some care. The role of employment agencies in shaping integration of migrants is seen as ambivalent. Although agencies make it easier for migrants to organise their life in the destination country (e.g. by providing them with accommodation), some of their activities can also lead to precariousness of work, and even to social and economic isolation (Meszmann 2019).

Ukrainian migrants form the largest group among almost all categories of migrants in Poland (be they work-permit holders, residence-card holders, students, etc.) (Wendt et al. 2018). However, their predominance among foreigners gaining employment in Poland under the simplified procedure is exceptional, given the way they account for around $95 \%$ of the declarations registered. This leaves conclusions and observations stemming from analyses presented here useful to researchers studying immigration from Ukraine into Poland in general. Interestingly, the volume of Ukrainian migration into eastern Poland and the border regions proves to be relatively limited. Thus, while geographical proximity is known to be a pivotal factor in trade, for example (Szejgiec \& Komornicki 2015), it does not prove significant where the geographical distribution of labour (mainly seasonal) migrants in Poland is concerned.

Limitations of our research needing to be addressed relate to the confinement of analyses to the single (albeit very important) channel of inflow of foreign labour into Poland that is the simplified procedure. There is thus a failure to address here, for example, the work permits whose number reached 235,000 in 2017. However, in terms of numbers of documents issued, there are many times more declarations than there are work permits. Moreover, the simplified procedure is used by less-experienced migrants above all, given its low cost and simplicity, as well as the active engagement of employment agencies. This implies that patterns describing the registration of the declarations offer a good overall measure of the most recent processes, as regards volume of inflow and the model for the geographical concentration of migration into Poland.

The final emphasis here should recall the special moment encapsulated here when it comes to labour-immigration developments in Poland. The situation is both particularly dynamic and difficult to anticipate. An unclear future as regards the kind of immigration policy Poland is to pursue adds further uncertainty. Where immigration from Ukraine specifically is concerned, the introduction of a visa-free (biometric passport-based) regime with the EU in 2017 has represented yet a further challenge for those wishing to forecast flows into Poland and Europe. All this means that trends determined by analysing declarations registered in the 2012-2017 period, though representing a key step in revealing the spatial development of immigration into Poland, will need to be followed up by further monitoring research that would be wrong to omit the local perspective. We argue that research on immigration into Poland, previously confining itself to such selected areas as Warsaw and Mazowieckie Voivodeship, has now entered a new phase, in which equal attention should be paid to national, regional and local perspectives.

\section{Ackonwledgements}

Analyses presented in this article were supported by funding of the Polish National Sciences Centre under the project "The economic integration of immigrants in a country in the intermediate phase of the migration cycle - Poland versus selected EU countries" grant no. DEC-2014/14/E/HS4/00387.

Editors' note:

Unless otherwise stated, the sources of tables and figures are the authors', on the basis of their own research. 


\section{References}

Brunarska Z., Kindler M., Szulecka M., TORUŃCZYK-RUIZ S., 2016. Ukrainian migration to Poland: A 'local mobility'? [in:] O. Fedyuk, M. Kindler (eds.), Ukrainian migration to the European Union: Lessons for migration studies, Heidelberg-New York-Dordrecht-London: Springer, pp. 115-131.

CAAĞLAR A., 2013. Circular migration between Hungary and Ukraine: historical legacies, the economic crisis, and the multidirectionality of 'circular' migration [in:] A. Triandafyllidou (ed.), Circular migration between Europe and its neighbourhood: Choice or necessity?, Oxford: Oxford University Press, pp. 141-165.

Castles S., de HaAs H., Miller M.J., 2014. The age of migration: International population movements in the modern world. London, New York: Palgrave Macmillan.

CSO, 2018. Foreigners on the national labour market - regional approach. Warsaw: Statistics Poland, https://stat.gov.pl/files/gfx/portalinformacyjny/pl/defaultstronaopisowa/6149/1/1/ cudzoziemcy_na_krajowym_rynku_pracy_w_ ujeciu_regionalnym-raport.pdf[15 March2019].

DrbohlaV D., Jaroszewicz M. (eds.), 2016. Ukrainian migration in times of crisis: Forced and labour migration. Prague: Charles University Press.

DuszCZyk M., MatuszCZYK K., 2018. The employment of foreigners in Poland and the labour market situation. Central and Eastern European Migration Review, vol. 7, no. 2, pp. 53-68.

Finel A., 2006. Przestrzenny wzorzec osiedlania się cudzoziemców w Polsce. Studia Demograficzne, vol. 2, pp. 49-67.

Górny A., 2017. All circular but different: Variation in patterns of Ukraine-to-Poland migration. Population Space and Place, vol. 23, no. 8, pp. 1-10.

Górny A., Grabowska-Lusińska I., LesińSKa M., OKÓLsKI M. (eds.), 2010. Transformacja nieoczywista. Polska jako kraj imigracji. Warszawa: Wydawnictwa Uniwersytetu Warszawskiego.

Górny A., KaCZMARCZYK P., 2018. A known but uncertain path: The role of foreign labour in Polish agriculture. Journal of Rural Studies, vol. 64, pp. 177-188.
Górny A., Kaczmarczyk P., Szulecka M., Bitner M., Okólski M., Siedlecka U., StefańCZYK A., 2018. Imigranci w Polsce w kontekście uproszczonej procedury zatrudniania cudzoziemców. Raport z badań. Warsaw: WISE Europa and Centre of Migration Research University of Warsaw, http://www.migracje.uw.edu.pl/ wp-content/uploads/2016/11/raport-power.pdf [15 April 2019].

Górny A., Kindler M., 2018. Cudzoziemcy w Polsce na przełomie XX i XXI wieku [in:] M. Lesińska, M. Okólski (eds.), 25 wykładów o migracjach, Warszawa: Wydawnictwo Naukowe Scholar, pp. 221-234.

Grabowska-lusińska I., Drbohlav D., Hars A. (eds.), 2011. Immigration puzzles: Comparative analysis of the Czech Republic, Hungary and Poland before and after joining the EU. Saarbrucken: Lap Lambert Academic Publishing.

Gulina A., Pozniak O., 2018. Ukrainian migration to Russia and Europe: New trends and its consequences. Journal of Social Policy Studies, vol. 16, no. 4, pp. 561-576.

HofMAN Y., 2013."My też tu jesteśmy" - głos ukraińskich studentów w Lublinie [in:] B. Rożnowski, T. Seniow (eds.), Integracja cudzoziemców w Polsce i Europie: perspektywa lokalna, Lublin: Instytut na Rzecz Państwa Prawa, pp. 79-88.

IgliCKA K., GMAJ K., 2013. Circular migration Patterns between Ukraine and Poland [in:] A. Traindafyllidou (ed.), Circular migration between Europe and its neighborhood: Choice or necessity? Oxford: Oxford University Press, pp. 166186.

JAKÓBCZYK-GrYSZKIEWICZ J., 2018. Czy imigracja jest szansq dla wyludniajacych się polskich miast? Wybrane rodzaje ruchów migracyjnych. Przegląd Geograficzny, vol. 90, no. 2, pp. 291308.

KLIMEK D., 2015. Funkcja ekonomiczna migracji zarobkowej z Ukrainy do Polski. Łódź: Politechnika Łódzka.

KorCelli P., 1997. The urban system of Poland in an era of increasing inter urban competition. Geographia Polonica, vol. 69, pp. 45-54.

Krzysztofik R., SZMYtKie R., 2018. Procesy depopulacji w Polsce w świetle zmian bazy ekonomicznej miast, Przeglad Geograficzny, vol. 90, no. 2, pp. 309-329. 
Meszmann T., 2019. Snakes or ladders? Job quality assessment among temp workers from Ukraine in Hungarian electronics. Central and Eastern European Migration Review, vol. 8, no. 1., pp. 75-93.

Napierata J., FiatKowSKA K., 2013. Mapping the market for employment agencies in Poland [in:] J.H. Frieberg, L. Eldring (eds.), Labour migrants from Central and Eastern Europe in the Nordic countries. Patterns of migration, working conditions and recruitment practices. Copenhagen: Nordic Council of Ministers, pp. 169-200.

Niewiadomska A., Sobolewska-Poniedziatek E., 2019. Imigracja zarobkowa w województwie lubuskim. Wiadomości Statystyczne, no. 3, pp. 42-62.

PRÁT Š., BUI T.M., 2018. A comparison of Ukrainian labor migration in the Czech Republic and Poland. East European Politics and Societies: and Cultures, vol. 32, no. 4, pp. 767-795.

Salaris L., Tedesco N., 2019. Migration and the labour market: Ukrainian women in the Italian care sector. Journal of International Migration and Integration, https://doi.org/10.1007/ s12134-019-00656-1).

SoKOŁOWICZ M.E., LISHCHYNSKYY I., 2018. Are Poland and Ukraine gravity centres for each other? Study on the labour migration patterns. Comparative Economic Research, vol. 21, no. 1, pp. 45-65.

Solga B., 2017. Migracje zagraniczne mieszkańców województwa opolskiego w latach 1990-
2015. Rocznik Ziem Zachodnich, vol. 1, pp. 324340.

Szejgiec B., Komornicki T., 2015. Spatial differentiation of Polish export linkages. Geographia Polonica, vol. 88, no. 1, pp. 173-178.

SzUlECKA M., 2016. Paradoxes of formal social control. Criminological aspects of foreigners' access to the Polish territory and labour market. Biuletyn Polskiego Towarzystwa Kryminologicznego, vol. 23, pp. 79-95.

ŚLESZYŃSKI P., 2018. Demograficzne wyzwania rozwoju regionalnego Polski. Studia Komitetu Przestrzennego Zagospodarowania Kraju PAN, vol. 183, pp. 225-247.

ŚleszYŃSKI P., BAńSKI J., DegórsKI M., KomorNICKI T., 2017. Delimitation of problem areas in Poland. Geographia Polonica, vol. 90, no. 2, pp. 131-138.

TORUŃCZYK-RUIZS., 2014. Neighbourhood ties and migrant networks: The case of circular Ukrainian migrants in Warsaw, Poland. Central and Eastern European Migration Review, vol. 3, no. 1, pp. 41-62.

Vollmer B.A., 2016. Ukrainian migration and the European Union: Dynamics, subjectivity, and politics. Basingstoke: Palgrave Macmillan.

WENDT J.A., LEWANDOWSKA I., WISKULSKI T., 2018. Migranci ukraińscy w Polsce w latach 20142017. Zeszyty Naukowe Politechniki Śląskiej, vol. 126, pp. 223-236. 


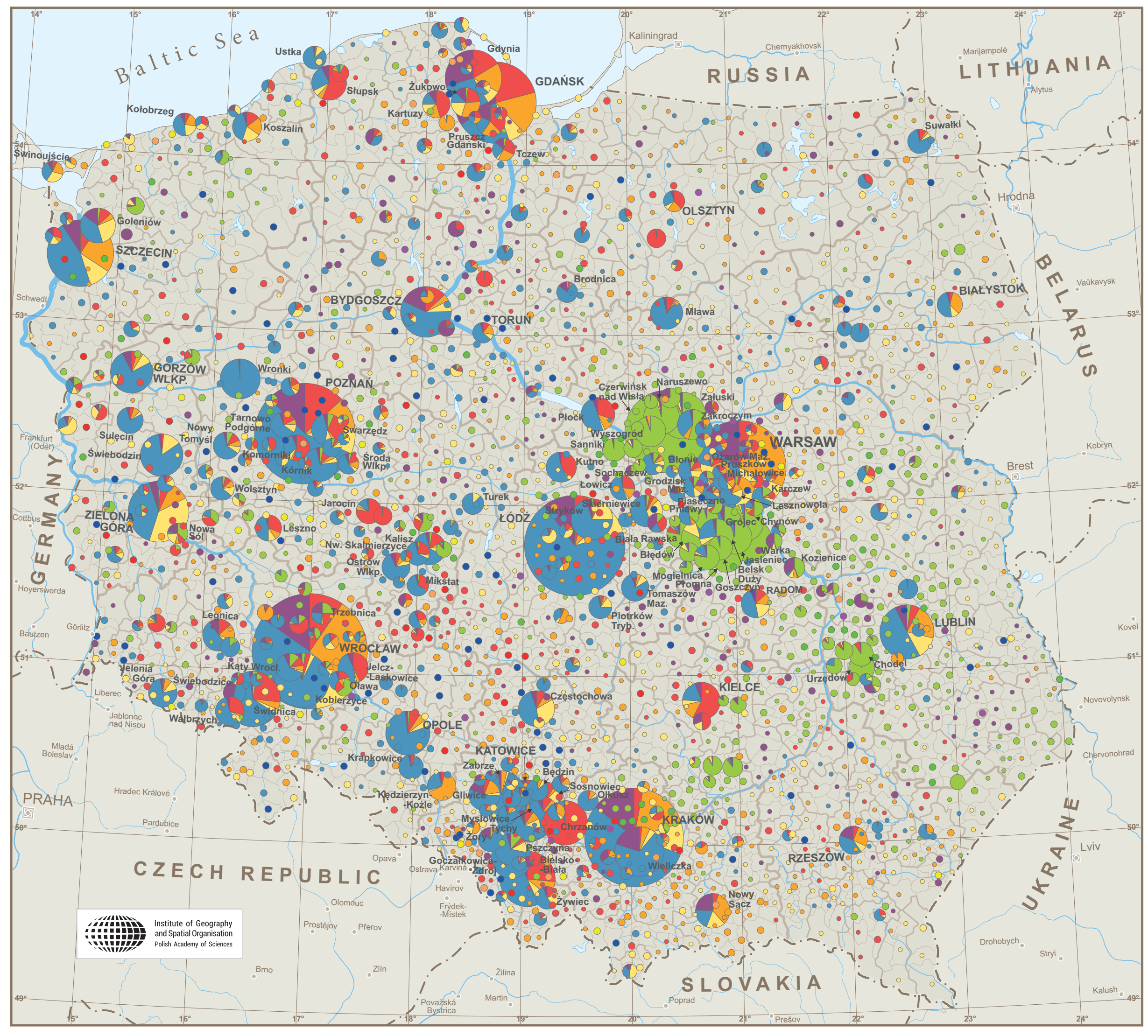

UKRAINIAN WORKERS IN POLAND* Agata Górny and Przemysław Śleszyński

Scale 1:3,000,000

$\stackrel{0 \quad 25 \quad 50 \quad 75 \quad 100 \mathrm{~km}}{\longleftarrow}$

Number of declarations according to the declared place of work by communes (gminas)

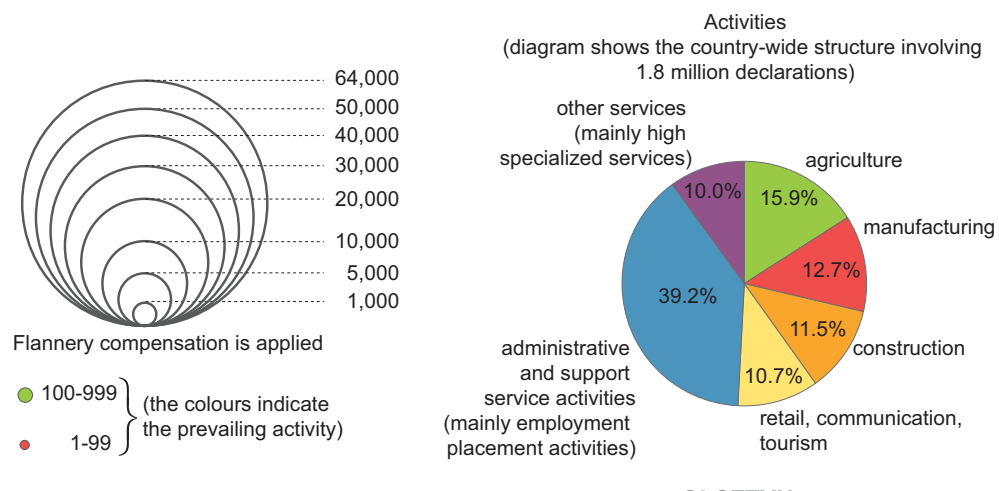

communes (gminas) > 3,000 Ukrainian workers are labeled (e.g. Mawa, OLSZTYN)

The volume of declarations by poviats

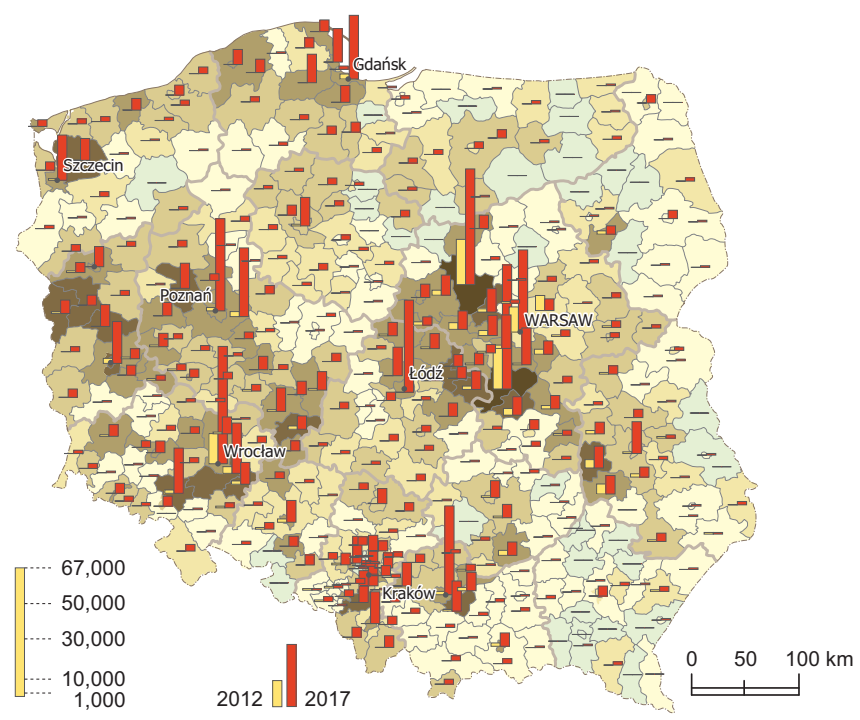

Number of declarations per 100 persons in working age (2017)

$13510 \quad 20$

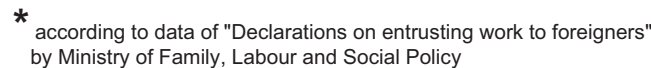

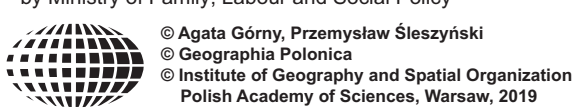

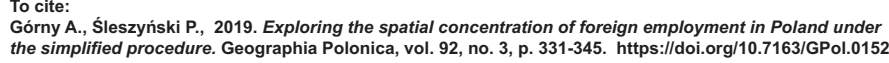

Figure 4. Numbers of employers' declarations of consent to employ a foreigner in Poland 2017, by gmina, and in line with the sector of employment (see Tab. 1)

Notes. Calculations in line with declared place of work, on the basis of $99.6 \%$ of all cases. Source: based on data from the Ministry of Family, Labour and Social Policy. 